\title{
The Influence of Dokuku Data Security and Service-Oriented Architecture On The Quality of Information
}

\author{
Algifanri Maulana ${ }^{1^{*}}$ and Harisno ${ }^{2}$ \\ 1,2 Bina Nusantara University, Jakarta, Indonesia \\ (Corresponding author) algifm@gmail.com*, harisno@binus.edu
}

\begin{abstract}
Information flowing like blood in the body, as well as within an organization, so that information is very important role in the organization. This research is to gain an overview of the data security Dokuku and determine the effect on the quality of the information so obtained information the extent to which data security and service-oriented architecture has an influence on the quality of information on business applications. In this study, a survey conducted on the existing city of Batam respondents who are users of business applications dokuku. Total population in this study using of user data that is in the city of Batam by using simple random sampling method using descriptive analysis and verification. The number of samples used in this study amounted to 97 respondents who use the questionnaire as a data collection tool. Security is usually described as freedom from danger or as a condition of salvation, computer security, modification, or destruction of computer systems and protection against unauthorized use or modification. Result of this research is a research document on data security dokuku that affect the quality of information. And also to the service-oriented architecture affects the quality of the information.
\end{abstract}

Keywords: Data security, Service-oriented architecture, Quality of information.

\section{INTRODUCTION}

Quality of information is very useful to determine useful information or not influenced or determined by three main aspects, namely, the accuracy, relevancy, and proper time [1]. Today information technology is growing rapidly, has been accelerating in many areas, as well as progress in the cause of software fits well with advances in hardware technology and sophistication. Directly or indirectly, information technology has become an essential part of many aspects of human life because so many simplicities. One of the important role of information technology in support of business activities on the internet. Many big companies now use the internet to sell products, product marketing, purchase stock from suppliers, and also provides services for customer service.

The magnitude of the benefits that can be achieved by using the internet to encourage the emergence of new businesses such as online sales, online store, online services, cloud data service. In addition, internet users increased from year to year, which grow rapidly prove that the internet can become a necessity in the future. The development of internet technology through web and mobile technology to make behavioral change in society and at the same time open up many new opportunities. Web technologies, mobile technology changed everything good that is interactive and dynamic. Many people may prefer to express themselves through networking, forming the community, collaborate, participate in various activities, as well as tools to market various products belonging to business development. The Internet not only belongs to the younger generation. This is due to the ease of access to the Internet and the flexibility of the Internet that can be accessed anywhere and at any time. When the Internet and mobile phone technology is advancing rapidly expanded and participate. So people can quickly access the internet phenomenon that resulted in the main flow of information not only in developed countries but also in Indonesia. Because of the speed of the internet is also beginning to look replaces the conventional mass media role in spreading a wide variety of news, but it can also make a tool for many companies that make use of information technology.

Dokuku is a simple business applications that come with the module cashier, sales, purchasing, inventory, accounting, multi-pronged and dashboard that allows access from anywhere making it easier for business owners to control their business. With this application, Managers dokuku is faster and more accurate in terms of knowing the data in business transactions online. Dokuku is the latest product from inforsys. Applications built using cloud technology has a high level of security of the data. Protection not only against data corruption, data thieves are also against hackers. Safe and comfortable. Interconnection of information systems through multimedia network increases. 
Currently installed information systems more accessible, time-sharing system and remote access causes a security problem to be one of the cons of data communication. During the time of universal electronic connectivity, there is often a distraction in the form of hackers, viruses. Therefore, data security absolutely becomes a very important issue, so it required a computerized network systems with a level of security can be guaranteed, and can avoid attacks, though in the end there will be a tradeoff between security and ease of access. Utilization and innovation made by the company, in terms of the development of information systems that have a very high data security that can provide the information very quickly and precisely. So it can help increase and monitor the development of the business users through an interactive online media. In addition, the company has a service-oriented architecture through collaboration to facilitate users in the running of the business. This not only as a replacement for the company as a whole system, but the system is a complementary application of business management are being made to increase the competitiveness and productivity of the user application system in line with current technological developments. So bring change impacts the development effort.

Based on the issue of formulations that have been outlined this research aims to know the: (1) to get an idea of dokuku data security (2) to obtain an overview of service oriented architecture (3) to get an idea about the quality of information (4) to find out the extent of the influence of dokuku data security for information quality (5) to find out the extent of the influence on quality of service-oriented information architecture(6) to find out the extent of the influence of dokuku data security architecture and service oriented quality information.

This research is expected to benefit both practically and theoretically, are as follows: (1) theoretically, reinforcing the theory that there is: (a) that the quality of the information is still very influenced or determined by the accuracy, relevance, and timely. So to reinforce the existing theory or add an existing theory, it is needed to provide input and information to all employers who use the system as the application materials to improve the learning results of dokuku. (2) In practice, giving feedback to the Company Inforsys Indonesia: (a) To make a difference in data security to information data stored. (b) The existence of knowledge data security architecture and service oriented Dokuku information quality.

\section{LITERATUR REVIEW}

\section{A. Data Security}

Security is usually described as freedom from danger or as a condition of salvation. Computer security goes into detail about the system of data protection against unauthorized authorization, modification, or destruction of computer systems and protection against unauthorized use or modification [3]. For the security of the data and information required for the implementation and maintenance of security programs to ensure three aspects: confidentiality, integrity and availability of information resources company [4]. Aspects of the security of the data measured by the ability of the system to anticipate the damage of data processing facilities with electricity died suddenly, the ability of the system to anticipate the damage caused by the animals, the ability of the system to anticipate the damage caused by viruses, the ability of the system to anticipate a result error accidental button presses, the ability of the system to anticipate employee access and unauthorized outsiders to the data, the ability of the system to anticipate the danger of fire in anticipation of the system capabilities, data security due to the long distance data transfer, the ability to anticipate the security system to back up the data on damage to hardware and software. Data security in a computer is very important. In many cases the user must repeat the work for days or even weeks or months because of damage or data loss.

\section{B. Service-Oriented Architecture}

Service-oriented architecture is an architectural style that combines services to support business processes and users [5]. Services in the software on the network can be in the data center or the internet which may be combined as needed to support the business to grow. The underlying concept of the architecture of web services technology is a Service Oriented Architecture (SOA) [6]. In this architecture, the application is modelled as a composition of a set of services provided by the component. The existence of these components can be dynamically discovered by the client, in the sense of not declared static but use the discovery mechanism to locate the where about of the component. Similarly, a client can request a dynamic service running anyway. SOA as an architecture technology that adheres to the principles of service oriented. When embodied in the technology of web services, SOA provides the potential for supporting these principles throughout the domains of business process automation and Enterprise [7]. Ideally, the SOA standards across the company, but to achieve this target require a planned transition carefully and can support the technology or system that still exists and is used. Any software that interacts with the consumer service, in example, there are applications that interact with the service, then the application is said to be a consumer service. There is also a service call and interact with other services. 


\section{Quality Of Information}

Quality of information is a function related to the value of the output produced by a system that is perceived by the user [8]. Quality of information is expected to help the company in determining the policies of the companies that have the capability of competitiveness. In the form of a strategy of information system must be aligned with business objectives so that business objectives can be achieved [9]. Companies can survive and succeed if enterprises plus the information technology strategy and goals in five competitive strategies that lower costs, differentiate, innovate, promote growth, and develop alliances [10]. Three dimensional measurement of the quality of the information, the third dimension is time, content, and form. Time dimension includes the timeliness, currency, frequency, period of time. Content dimensions include accuracy, relevance, completeness, brevity, scope, and performance. While the dimensions of the form including detailed clarity, order, presentations, and media.

\section{RESEARCH METHOD}

Design research is the process that is required to perform data analysis so as to be able to answer the research questions in the problem formulation must contain everything associated with the implementation of research later [12]. This research is descriptive research purpose to find out the effect of the independent variables and data security architecture dokuku service oriented towards the dependent variable is the quality of the information. Data collection methods used in this study is a questionnaire in the form of written questions given to the respondent.

\section{RESULT \& DISCUSSION}

Dokuku characteristics application user in Batam city respondent based on gender and through the study of random sampling where the author deploys the questionnaires was 97 and that the respondent is the user application dokuku in Batam city aged 17 years or over. From the results of questionnaires filling out the importance of the profile of respondents based on the sex of male-male, there were 43 people, there are 54 women, aged $20-30$ years of 79 people, 30 years or older, there were 18 people, based on the latest education, there are 55 high school, there were 31 people, D3 S1 there's11 people, based on the work that the staff there were 90 people, there were 7 people Manager.

\section{A. Validity Of Data}

Table 1. Validity Of Data

\begin{tabular}{|c|c|c|c|c|c|}
\hline $\begin{array}{c}\text { No } \\
\text { Statement }\end{array}$ & $\begin{array}{c}\text { Coefficient } \\
\text { Correlation } \\
\text { Data Security (X1) }\end{array}$ & $\begin{array}{c}\text { Coefficient } \\
\text { Correlation } \\
\text { SOA } \\
\text { (X2) }\end{array}$ & $\begin{array}{c}\text { Coefficient } \\
\text { Correlation } \\
\text { Quality of Information } \\
(\mathrm{Y})\end{array}$ & Standar & Result \\
\hline 1 & 0,699 & - & - & 0,361 & Valid \\
\hline 2 & 0,454 & - & - & 0,361 & Valid \\
\hline 3 & 0,490 & - & - & 0,361 & Valid \\
\hline 4 & 0,480 & - & 0,698 & 0,361 & Valid \\
\hline 5 & 0,375 & - & 0,829 & 0,361 & Valid \\
\hline 6 & 0,500 & 0,374 & 0,556 & 0,361 & Valid \\
\hline 7 & 0,701 & - & - & 0,361 & Valid \\
\hline 8 & - & 0,390 & - & 0,361 & Valid \\
\hline 9 & 0,478 & - & 0,816 & 0,361 & Valid \\
\hline 10 & - & 0,463 & 0,855 & 0,361 & Valid \\
\hline 11 & 0,560 & 0,458 & 0,830 & 0,361 & Valid \\
\hline 12 & 0,684 & 0,697 & 0,866 & 0,361 & Valid \\
\hline 13 & 0,424 & 0,796 & 0,809 & 0,361 & Valid \\
\hline 14 & 0,684 & 0,525 & 0,890 & 0,361 & Valid \\
\hline 15 & - & & 0,816 & 0,361 & Valid \\
\hline 16 & - & & 0,981 & 0,361 & Valid \\
\hline 17 & - & & 0,855 & 0,361 & Valid \\
\hline 18 & - & & 0,968 & 0,361 & Valid \\
\hline
\end{tabular}

B. 
Test the validity of the data used to measure the instrument which is used as a measuring tool. If the value of the instrument is valid, then the instrument can be used to measure what should be measured. Here are the results for each test the validity of the study variables consisting of independent variables and variables related.

Before performing the questionnaire as a whole, it is necessary first to test questionnaires to 30 respondents. Beyond 30 respondents who had been giving out a statement in the form of a questionnaire, so that the data in the form of grain such statement has been obtained, for variabel X1 after pre test have valid 12 statement, variabel X2 have valid 7 statement and variabel $Y$ have valid 13 statement tested using IBM SPSS version 20.

C. Reliability Of Test

Test Reliability data is used to gauge whether or decent reliable research instrument used as a measuring tool.

\begin{tabular}{|c|c|c|}
\hline \multicolumn{3}{|c|}{ Table 2. Results Realibity Test } \\
\hline $\begin{array}{c}\text { Cronbach's Alpha } \\
\text { Data Security }\end{array}$ & $\begin{array}{c}\text { Cronbach's Alpha } \\
\text { SOA }\end{array}$ & $\begin{array}{c}\text { Cronbach's Alpha } \\
\text { Quality Of Information }\end{array}$ \\
\hline .778 & .561 & .961 \\
\hline \multicolumn{3}{|c|}{ N of Items } \\
\hline 12 & 7 & 13 \\
\hline
\end{tabular}

D. Normality Of Test

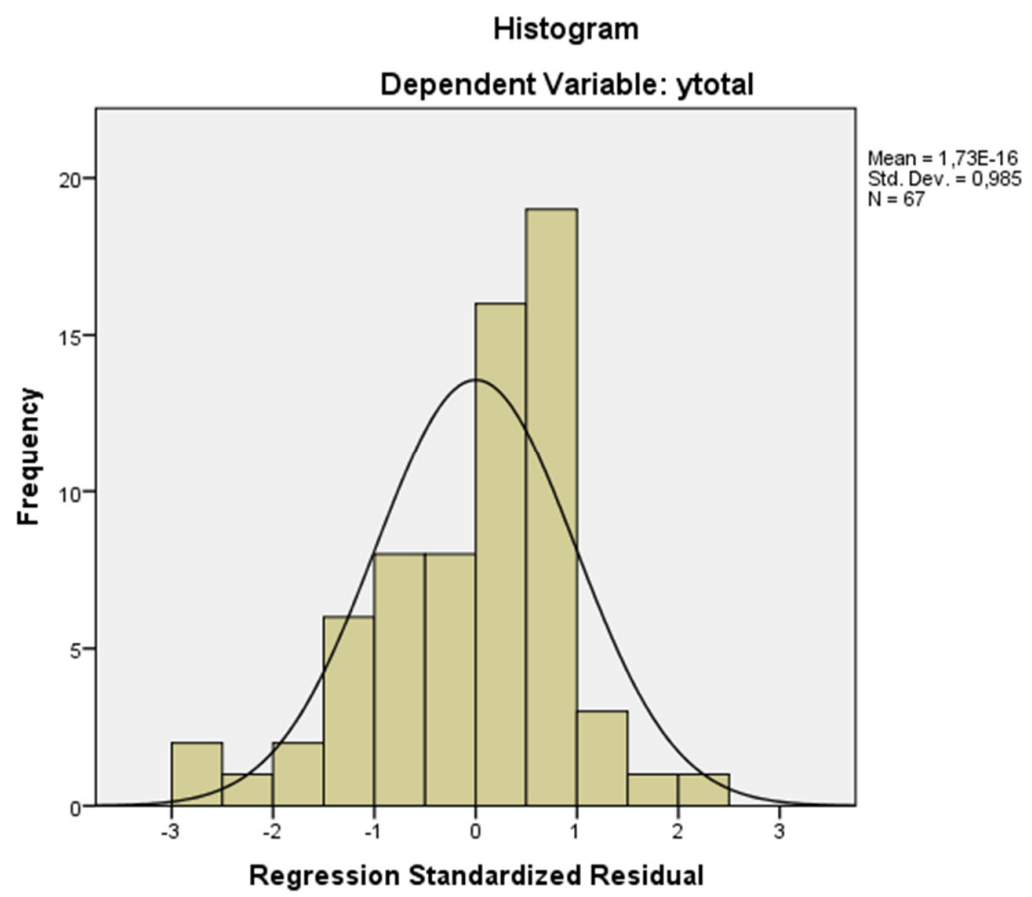

Figure 1. Normality Of Test

Normality of test results showed that the results of the histogram if the data using SPSS version 20 tend to straight, not slanted to the right or to the left to form a Bell. It can be said that the regression models have a normal or near-normal distribution, so that the regression model of qualified used to predict the dependent variable is the quality of the information. 


\section{E. Multicollinearity Test}

Table 3. Multicolinearity Test

\begin{tabular}{|c|c|c|c|c|c|c|}
\hline \multicolumn{2}{|c|}{ Model } & \multicolumn{2}{|c|}{ Unstandardized Coefficients } & \multirow{2}{*}{$\begin{array}{c}\text { Standardized } \\
\text { Coefficients } \\
\text { Beta }\end{array}$} & \multicolumn{2}{|c|}{ Collinearity Statistics } \\
\hline & & $B$ & Std. Error & & Tolerance & VIF \\
\hline \multirow{3}{*}{1} & (Constant) & 63,514 & 10,608 & & & \\
\hline & x1 total &, 574 & ,135 & ,401 &, 925 & 1,082 \\
\hline & $\times 2$ total & $-1,198$ & ,244 &,- 462 & ,925 & 1,082 \\
\hline
\end{tabular}

a. Dependent Variable: ytotal

Multicollinearity test results indicate that the variable has a value of VIF Data Security at 1.082 and X2 representing Service Oriented Architecture has VIF value of 1.082. Under a provision stating that if VIF $<10$ then the level of collinearity can be tolerated, then the level of collinearity on the variables X1 and X2 can be tolerated. This means it does not happen collinearity between these variables.

\section{F. Effect test}

Multiple linear regression test was used to test the influence of more than one variable the dependent variable are independent of. In multiple regression with dependent variables that are affected by more than one independent variable.

Table 4. Results Analysis Data Security Correlation Coefficient (X1) and Service Oriented Architecture (X2) on Information Quality (Y)

Coefficientsa

\begin{tabular}{|l|l|r|r|r|r|r|}
\hline \multicolumn{2}{|c|}{ Model } & \multicolumn{2}{|c|}{ Unstandardized Coefficients } & \multicolumn{1}{c|}{$\begin{array}{c}\text { Standardized } \\
\text { Coefficients }\end{array}$} & Sig. \\
\cline { 3 - 6 } & (Constant) & 63,514 & 10,608 & & \multicolumn{1}{c|}{ Beta } & \\
\hline \multirow{3}{*}{1} & x1 total &, 574 &, 135 &, 401 & 4,255 &, 000 \\
\cline { 2 - 6 } & x2 total & $-1,198$ &, 244 &,- 462 & $-4,903$ &, 000 \\
\hline
\end{tabular}

a. Dependent Variable: ytotal

Based on the table above was obtained in a linear regression analysis regression estimation model is $Y=0,574+X 1$ $63,514 \times 2$ 1.198. From this equation can be explained that: (a) the variable data security has marked the positive direction of the coefficient on the quality of information, whereas the service oriented architecture has a negative direction variable coefficient on the quality of the information. (B) The value of the constants of 63,514; meaning if data security variables (X1) and service-oriented architectures (X2) value is 0 (zero), then the variable interest rate the quality of information $(Y)$ value 63,514. (C) variable data security regression coefficients $(X 1)$ has a value of 0,574 ; that means that if other independent variable value is fixed and variable data security increases the score, it will improve the quality of information by 0,574 . Positive coefficient, meaning that there is a positive relationship between data security with quality information. Further enhance the value of the variable data security, then improve the quality of information. (D) The regression coefficient of the variable service oriented architecture (X2) has a value of-1,198; that means that if other independent variable value is fixed and variable quality of information has decreased in value, it will decrease the quality of the information-1.198. The coefficient is negative the negative relationship between mean there is service oriented architecture with the quality of the information. The lower the value of the variable, quality of service-oriented architecture of information decreases.

G. $R^{2}$ Test

The coefficient of determination is a quantity that indicates the amount of variation in the dependent variable can be explained by the independent variables. In other words, the determination of the coefficient is used to measure how much variables the dependent variable in the independent explains. The value specified by the value of the coefficient of determination $\mathrm{R}$ square as shown in the following table: 
Table 5. The coefficient of determination Model Summary

\begin{tabular}{|l|r|r|r|r|r|}
\hline Model & $\mathrm{R}$ & R Square & $\begin{array}{c}\text { Adjusted R } \\
\text { Square }\end{array}$ & $\begin{array}{c}\text { Std. Error of } \\
\text { the Estimate }\end{array}$ & Durbin-Watson \\
\hline 1 &, $689^{a}$ &, 475 &, 459 & 5,551 & 1,187 \\
\hline
\end{tabular}

a. Predictors: (Constant), $\times 2, \times 1$

b. Dependent Variable: $y$

Regression calculation results can be seen that the coefficient of determination ( $R$ Square) obtained at 0.475 . This means that $47.5 \%$ variation of the variable quality of information can be explained by the variable data security and service-oriented architecture, while the remaining $62.5 \%$ is explained by other variables that are not proposed in this study.

\section{H. Simultaneous Of Test}

$F$ test is used to see the effect of simultaneously between independent variables and the dependent variable. F-test value of each independent variable on the dependent variable analyzed using SPSS version 20 software to perform data processing, while the values of this test can be seen in the table below:

Table 6. Regression Analysis Simultaneously

\begin{tabular}{|l|l|r|r|r|r|r|}
\hline \multicolumn{2}{|l|}{ Model } & $\begin{array}{c}\text { Sum of } \\
\text { Squares }\end{array}$ & df & Mean Square & F & Sig. \\
\hline \multirow{3}{*}{1} & Regression & 1786,497 & 2 & 893,249 & 28,993 &, $000^{\mathrm{b}}$ \\
\cline { 2 - 8 } & Residual & 1971,771 & 64 & 30,809 & & \\
\cline { 2 - 8 } & Total & 3758,269 & 66 & & & \\
\hline
\end{tabular}

a. Dependent Variable: $y$

b. Predictors: (Constant), $\times 2, \times 1$

Based on table above can be seen that value of $\mathrm{F}$ calculated is 28.993 and a significance level of 0.000 . The results of this study indicate that $\mathrm{HO}$ is rejected and $\mathrm{H} 1$ is accepted because of Sig. $0.000<0.05$. It means that the proposed hypothesis in this study received there is a simultaneous influence of variable data security and service-oriented architecture to quality information.

\section{CONCLUSION}

Based on this research result can be concluded are as follow: (1) Security of data according to application users dokuku affects the quality of information, (2) Service-oriented architecture by users is very important to obtain information, (3) Quality of information is perceived very high influence by users dokuku, (4) Data security is quite a positive effect on the quality of information, (5) service-oriented architecture is quite positive and significant impact on the quality of information, (6) data security and service-oriented architecture greatly affect the quality of the information simultaneously.

\section{REFERENCES}

[1] Mulyanto, A. (2009). Sistem Informasi Konsep dan Aplikasi . Yogyakarta: Pustaka Pelajar.

[2] Kartajaya, H. (2008). 8 Revolusi Sikap Menjadi Entrepreneur. Jakarta: Elex Media Komputindo.

[3] Tipton, H. F. (2004, September 24). Handbook of Information Security Management: Access Control. Retrieved Agustus 28, 2014, from Types of Information of Security Controls: https://www.cccure.org/Documents/HISM/003-006.html

[4] Imran, B. R. (2007). Studi Klasifikasi Keamanan Data Untuk Enterprise. Laboratorium Sistem Kendali Komputer , 2.

[5] Hugos, M., \& Hulitzky, D. (2010). Service Oriented Architecture. In M. H. Hulitzky, What every business needs to know about Cloud Computing (pp. 52-54). Canada: John Wiley \& Sons, Inc.

[6] Rusiawan, F. D. (2004). Tinjauan Keamanan Web Service. Keamanan Sistem Lanjut, 3-4.

[7] Erl, T. (2005). Service-Oriented Architecture: Concept, Technology, and Design. USA: Prentice Hall.

[8] Jayashetty, S., \& M, P. K. (2006). Adopting Service Oriented Architecture increases the flexebility of your enterprise. Infosys , 2-10.

[9] Mulyanto, A. (2009). Sistem Informasi Konsep dan Aplikasi . Yogyakarta: Pustaka Pelajar.

[10] Turban. (2007). Decision Support Systems and Intelligent Systems. Yogyakarta: Andi Publisher.

[11] Sugiyono, P. D. (2010). Metode Penelitian Pendidikan Pendekatan Kuantitatif. Bandung: CV Alfa Beta.

[12] Husein, U. (2004). Metode Penelitian Untuk Skripsi dan Tesis bisnis. Jakarta: PT. Raja Grafindo Persada.

[13] Riduwan. (2010). Metode dan Teknik Menyusun Proposal Penelitian. Bandung: Alfabeta.

[14] Bungin, B. (2011). Metode Penelitian Kuantitatif. Jakarta: Kencana.

[15] Riduwan. (2008). Belajar Mudah Penelitian untuk Guru Karyawan dan Pemula. Jakarta: Alfabeta. 